\title{
Saxifraga viridiflora (Saxifragaceae), an unusual new species from Guangxi, China
}

\author{
Xin-Jian Zhang ${ }^{1,2^{*}}$, Quan-Sheng Fu', ${ }^{1,2}$, Jun-Tong Chen ${ }^{1,2}$, Li-Juan $\mathrm{Li}^{2,3}$, \\ Peng-Rui Luo ${ }^{1,2}$, Jing-Yi Peng ${ }^{4}$, Xian-Han Huang ${ }^{1}$, Hang Sun', Tao Deng ${ }^{\prime}$
}

I CAS Key Laboratory for Plant Diversity and Biogeography of East Asia, Kunming Institute of Botany, Chinese Academy of Sciences, Kunming 650201, Yunnan, China 2 University of Chinese Academy of Sciences, Beijing 100049, China 3 CAS Key Laboratory of Plant Germplasm Enhancement and Specialty Agriculture, Wuhan Botanical Garden, Chinese Academy of Sciences, Wuhan 430074, Hubei, China 4 College of Biology and Environmental Sciences, Jishou University, Jishou 416000, Hunan, China

Corresponding authors: Tao Deng (dengtao@mail.kib.ac.cn), Hang Sun (sunhang@mail.kib.ac.cn)

Academic editor:AlinaFreire-Fierro | Received24August 2021 |Accepted26September 2021 | Published25October 2021

Citation: Zhang X-J, Fu Q-S, Chen J-T, Li L-J, Luo P-R, Peng J-Y, Huang X-H, Sun H, Deng T (2021) Saxifraga viridiflora (Saxifragaceae), an unusual new species from Guangxi, China. PhytoKeys 184: 19-26. https://doi. org/10.3897/phytokeys. 184.73421

\begin{abstract}
Saxifraga viridiflora, a remarkable new species of the genus Saxifraga sect. Irregulares (Saxifragaceae) from Guangxi, is described and illustrated herein. This new species morphologically differs from all known $S$. sect. Irregulares taxa by its greenish petals, verruculose sepals, and thick leathery leaf blade abaxially scarlet with white spots.
\end{abstract}

\section{Keywords}

China, Guangxi, new species, Saxifragaceae, taxonomy

\section{Introduction}

Saxifraga Linnaeus, the largest genus of Saxifragaceae, comprises more than 440 species widely distributed throughout the Northern Hemisphere (Pan et al. 2001; Tkach et al. 2015a, b). Previous molecular phylogenetic studies suggested that Saxifraga is monophyletic, providing that $S$. sect. Micranthes (Haw.) D. Don is excluded

\footnotetext{
* The authors contributed equally to this study.
}

Copyright Xin-jian Zhang et al. This is an open access article distributed under the terms of the Creative Commons Attribution License (CC BY 4.0), which permits unrestricted use, distribution, and reproduction in any medium, provided the original author and source are credited. 
(Soltis et al. 1996; Prieto et al. 2013; Deng et al. 2015; Tkach et al. 2015a, b). Recent molecular phylogenetic research covered at least 13 sections and 9 subsections within the genus (Tkach et al. 2015b). S. sect. Irregulares Haw., characterized by zygomorphic flowers with two elongated petals and stamens with club-shaped filaments (Tkach et al. 2015b), is the ancestral clade of Saxifraga first described by Haworth (Haworth 1803; Soltis et al. 2001; Zhang et al. 2015; Tkach et al. 2015b; Zhang et al. 2019b). This section currently comprises 16 species mainly distributed in East Asia (Magota et al. 2021).

China has a vast territory with a wide range of complex and diverse topographies and soils and covering several climate types, which contribute to the wealth of Chinese botanical diversity (Sun et al. 2017; Chen et al. 2018). Twelve species of Saxifraga sect. Irregulares are native to China, including the recently reported new species, $S$. $d a$ qiaoensis F.G.Wang \& F.W.Xing (Wang et al. 2008), S. kegangii D.G.Zhang, Y.Meng \& M.H.Zhang (Zhang et al. 2017), S. luoxiaoensis W.B.Liao, L.Wang \& X.J.Zhang (Zhang et al. 2018), S. shennongii L.Wang, W.B.Liao \& J.J.Zhang (Zhang et al. 2019a), and S. damingshanensis W.B.Liao, W.Y.Zhao \& J.H.Jin (Zhao et al. 2019).

In 2021, we inadvertently found a peculiar plant photograph posted on Baidu Tieba (https://tieba.baidu.com/), one of the most used Chinese communication platforms, and immediately deemed it to be a new species of Saxifraga sect. Irregulares, as it possesses zygomorphic flowers with two elongated petals and stamens with club-shaped filaments, but its petals are greenish, which cannot be found in any existing species of Saxifraga sect. Irregulares. We contacted the author of this photograph, Mr. Luo Dexuan, for phenological and geographical information regarding this specimen, and conducted fieldwork for this undescribed specimen. Subsequent morphological comparisons supported the status of the taxon as a new species, and it is described herein.

\section{Taxonomy treatment}

Saxifraga viridiflora X.J.Zhang, T.Deng, J.T.Chen \& H.Sun, sp. nov. urn:Isid:ipni.org:names:77221295-1

Figs 1, 2

Type. China. Guangxi: Guilin City, Yongfu County, Baishou Town, 10946'58.99"E, $25^{\circ} 5^{\prime} 15.5^{\prime \prime N}, 586 \mathrm{~m}$ alt., 27 June 2021, X.J. Zhang, D.X. Luo Zhangxj98 (Holotype: KUN!; Isotypes: JIU!, SYS!).

Diagnosis. Saxifraga viridiflora is easily distinguished from any other species of Saxifraga sect. Irregulares by having greenish petals (vs. white petals). S. viridiflora morphologically resembles $S$. epiphylla and $S$. kegangii, but is distinct from the latter two in its leaf blade abaxially scarlet with white spots (vs. abaxially greenish/reddish with brown or yellow-green spots), and sepals with verruculose surface (vs. sepals without verruculose surface) (Table 1). 


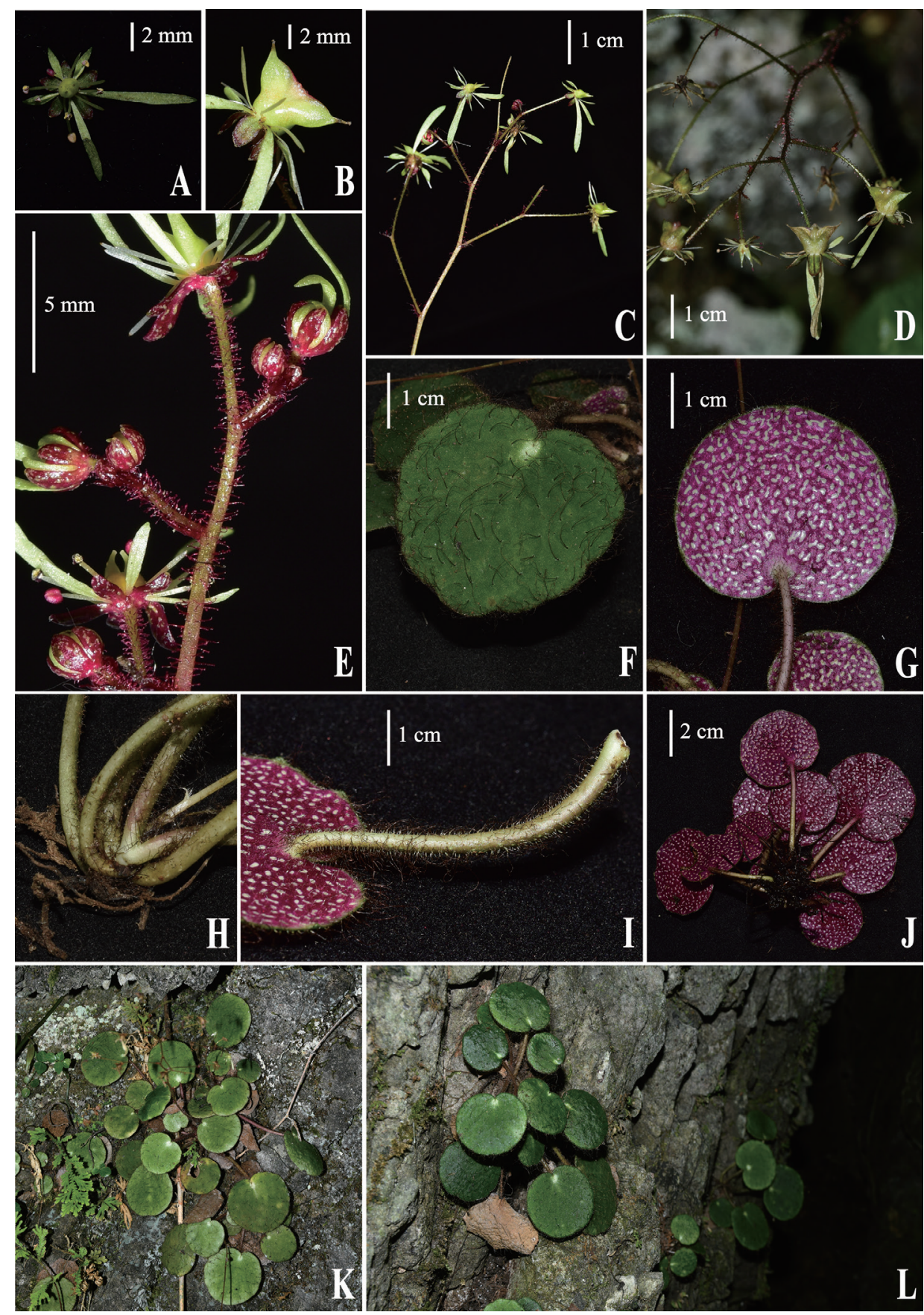

Figure I. Saxifraga viridiflora X.J.Zhang, T.Deng, J.T.Chen \& H.Sun, sp. nov. A flower, petals 5, greenish $\mathbf{B}$ fruit, capsule winged when mature $\mathbf{C}$ inflorescence $\mathbf{D}$ infructescence $\mathbf{E}$ pedicels glandular pubescent; sepals red, glabrous, abaxially white verruculose $\mathbf{F}$ adaxial leaf surface dark green, crisped villous $\mathbf{G}$, J abaxial leaf surface scarlet, with white spotted, crisped villous $\mathbf{H}$ rhizomes crisped villous, petiole base unsheathed $\mathbf{I}$ petiole with crisped villous $\mathbf{K}$, $\mathbf{L}$ plants and habitat. 


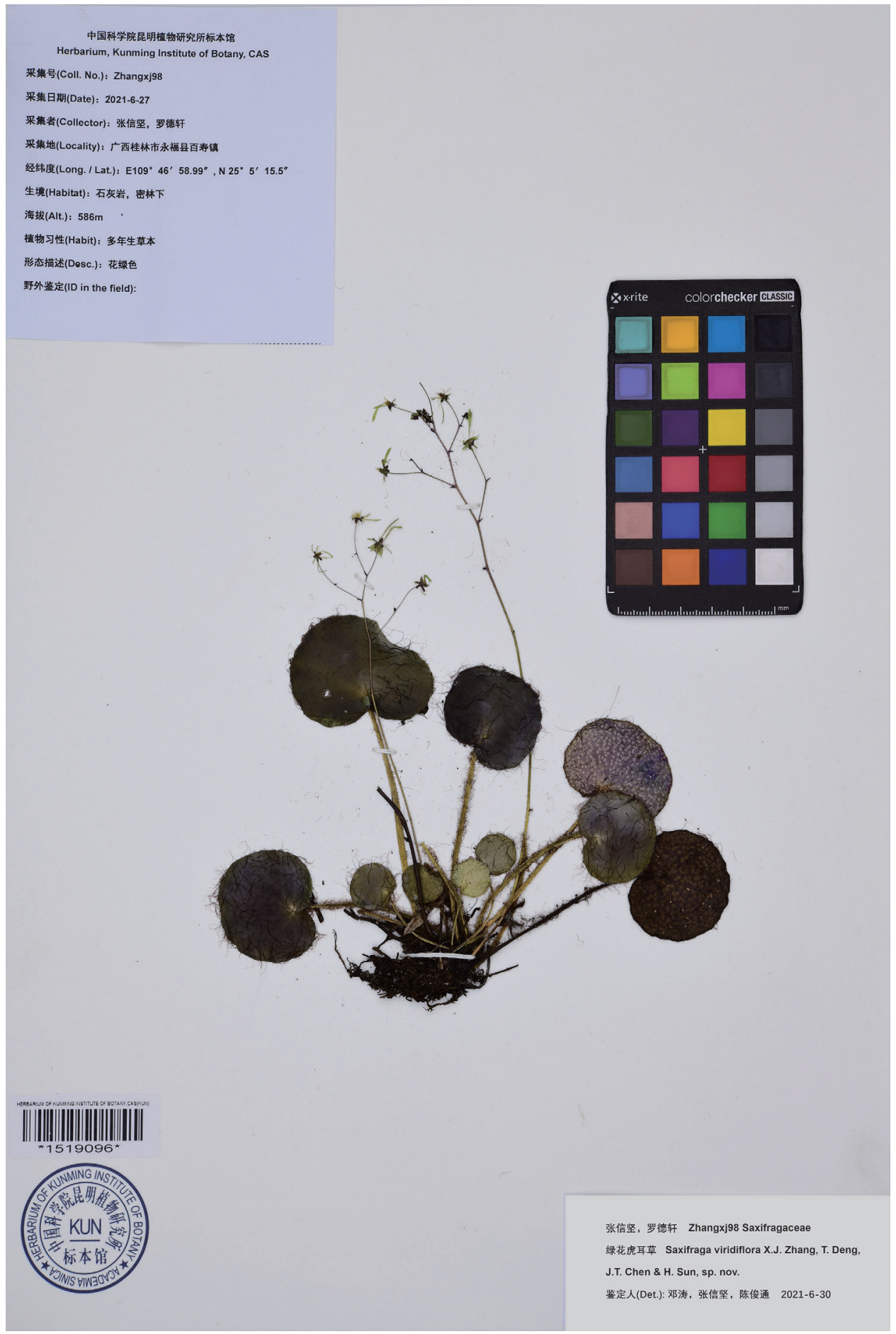

Figure 2. Photograph of the holotype of Saxifraga viridiflora X.J.Zhang, T.Deng, J.T.Chen \& H.Sun, sp. nov. (Zhangx98, KUN1519096). 
Table I. Diagnostic characters of Saxifraga viridiflora and comparison with other related species of $S$. sect. Irregulares.

\begin{tabular}{|c|c|c|c|}
\hline Characters & S. viridiflora sp. nov. & S. epiphylla & S. kegangii \\
\hline Foliar embryo & absent & present & absent \\
\hline Leaf shape & reniform to orbicular & ovate & fan-shaped to orbicular \\
\hline Leaf margin & shallowly crenate to subentire & undulate, thickly dentate & entire or $8-10$-crenate \\
\hline Leaf texture & thick leathery to fleshy & leathery & leathery \\
\hline $\begin{array}{l}\text { Abaxial surface of leaf } \\
\text { blade }\end{array}$ & scarlet, with white spotted & $\begin{array}{l}\text { gray-green to red, with brown or } \\
\text { yellow-green spotted }\end{array}$ & $\begin{array}{l}\text { gray-green, with yellow-green } \\
\text { spotted }\end{array}$ \\
\hline Trichomes on leaf & both surfaces crisped villous & both surfaces glandular hispid & $\begin{array}{l}\text { adaxially glabrous, abaxially } \\
\text { glabrous or sparsely hispid }\end{array}$ \\
\hline Petals & greenish & $\begin{array}{c}\text { white, the base of three smallest } \\
\text { petal with yellow spot }\end{array}$ & $\begin{array}{c}\text { white, the base of three smallest } \\
\text { petal with yellow spot }\end{array}$ \\
\hline Sepals & $\begin{array}{c}\text { red, glabrous, abaxially white } \\
\text { verruculose }\end{array}$ & $\begin{array}{l}\text { greenish, abaxially and marginally } \\
\text { glandular hairy, without verruculose }\end{array}$ & $\begin{array}{l}\text { greenish, abaxially and marginally } \\
\text { glandular hairy, without verruculose }\end{array}$ \\
\hline
\end{tabular}

Description. Perennial herbs, $12-30 \mathrm{~cm}$ tall. Stolons absent. Rhizomes rather short. Leaves all basal; petiole 5-12 cm long, crisped villous dark-purple (ca. $6 \mathrm{~mm}$ ); leaf blade reniform, thick leathery, $2.5-4.0 \mathrm{~cm}$ long $\times 3.5-5.3 \mathrm{~cm}$ wide, base cordate, margin undulate, apex obtuse, both surfaces crisped villous dark-purple $(5.0-9.0 \mathrm{~mm}$ long), adaxially greenish, abaxially purple or dark red, with white spots. Inflorescence paniculate, ca. $20 \mathrm{~cm}$ long. 5-10-flowered; branches $2.0-3.0 \mathrm{~cm}$ long, glandular pubescent, 1-2-flowered; pedicels slender, $1.0-2.0 \mathrm{~cm}$ long, glandular pubescent. Flowers zygomorphic; sepals 5, spreading to reflexed, narrowly ovate, $2.5-3.5 \mathrm{~mm}$ long $\times 1.5-2 \mathrm{~mm}$ wide, glabrous, abaxially red, with white verruculose, adaxially greenish, 3-5-veined, apex obtuse. Petals 5, greenish, margin entire, glabrous, apex acute; the three smallest lanceolate, $3.0-4.0 \mathrm{~mm}$ long $\times 1.0-1.2 \mathrm{~mm}$ wide, 3 -veined; the two largest lanceolate oblong, $0.7-1.4 \mathrm{~cm}$ long $\times 1.0-1.2 \mathrm{~mm}$ wide, 3-veined. Stamens 10, 3.2-4.0 mm long. Ovary ovoid, 1.5-2.0 mm long, disc obscure; styles divergent ca. 1.0-1.8 mm long. Capsule beaks winged when mature, carpels $5-7 \mathrm{~mm}$ long $\times 3-4 \mathrm{~mm}$ wide. Seeds elliptic, the two sides slightly bent, ca. $0.6 \mathrm{~mm}$ long.

Etymology. The specific epithet refers to the flowers of this new species that are green throughout the flowering period, differing from those of all other known Saxifraga sect. Irregulares species. The Chinese name is given as “绿花虎耳草” (1ù huā hŭ ěr căo), referring to the greenish petals of the new species.

Phenology. In a two year personal observation of this new species in its native range, Guangxi. Guilin City (Luo Dexuan, pers. comm.), S. viridiflora was flowering from April to July and fruiting from June to August.

Distribution and ecology. The new species, Saxifraga viridiflora, is currently known only from Yongfu County, Guangxi Province, China. It was observed to grow on dry limestone under dense jungles at altitudes between 500 and $600 \mathrm{~m}$.

Paratypes. China. Guangxi. Guilin City, Yongfu County, Baishou Town, $109^{\circ} 46^{\prime} 49.3^{\prime \prime E}, 25^{\circ} 5^{\prime} 16.1^{\prime \prime N}, 547 \mathrm{~m}$ alt., 10 July 2021, X.J. Zhang, L.J. Li, J.Y. Peng, P.R. Luo Deng12030 (KUN); same locality, $575 \mathrm{~m}$ alt., 27 June 2021, X.J. Zhang, D.X. Luo Zhangxj99 (KUN). 


\section{Discussion}

The new species Saxifraga viridiflora has zygomorphic flowers and stolons absent, which indicate a position in $S$. sect. Irregulares ser. Rufescentes. Saxifraga viridiflora is distinct from all known sect. Irregulares taxa by its greenish petals, verruculose sepals, and thick leathery leaf blade abaxially scarlet with white spots.

Geographically, Saxifraga viridiflora was only found in Yongfu County of Guangxi Province, China. It grows only on dry rocks under dense jungles in limestone area, whereas other related species of sect. Irregulares usually grow on damp cliffs and rocks nearby valleys. Here we argue that the environmental heterogeneity plays an important role in the differentiation of the species in sect. Irregulares, given the leaf blade of Saxifraga viridiflora is thick leathery or fleshy (grow on dry rocks), while the leaf blade of other related species of sect. Irregulares are mainly papery or leathery (grow on damp rocks).

Notably, only seven species of Saxifraga sect. Irregulares were recorded in "Flora of China" (Pan et al. 2001). However, six new species of S. sect. Irregulares were discovered in China in recent years, provided that Saxifraga viridiflora is counted. Furthermore, most of these new species were confined to a narrow geographical range. Species richness of $S$. sect. Irregulares has been quite underrated, and more field investigations and phylogenetic analyses are needed to infer its biodiversity and speciation history.

Since several new species of $S$. sect. Irregulares have been published in recent years, we include here an identification key to include all species known so far for this section.

\section{Identification key to Saxifraga sect. Irregulares}

1 Stolons arising from axils of basal leaves, filiform S. stolonifera

Stolons absent 2

Aerial stems developed; leaves cauligenous

S. sendaica

Aerial stems not developed; leaves radical.................................................. 3

Leaf blade abaxially spotted

Leaf blade abaxially usually concolorous

Leaf blade elliptic to oblong, base cuneate.

S. kwangsiensis

Leaf blade fan-shaped or ovate to broadly so, base cordate or peltate. .5 Leaf blade with foliar embryos in sinus adaxially S. epiphylla Leaf blade without foliar embryos.

Leaf base cordate.

Leaf blade papyraceous, apex acute

S. mengtzeana

Leaf blade thickly coriaceous, apex obtuse.

Leaf margin shallowly crenate to subentire.

9 Capsule beaks winged; leaf lobes margin irregularly dentate....S. luoxiaoensis Capsule beaks divergent; leaf lobes margin entire 
11 Leaf blade abaxially gray-green with yellow-green spots. S. kegangii

- Leaf blade abaxially scarlet with white spots S. viridiflora

12 Longest petal serrate at margin. S. fortunei

14 Upper petals nearly lanceolate, not spotted

16 Flowering stem and inflorescence reddish long glandular villous

\section{Acknowledgements}

The authors are deeply grateful to Mr. Luo Dexuan, who first discovered this species, for offering kind assistance during the fieldwork. This study was supported by grants from the Biodiversity Survey and Assessment Project of the Ministry of Ecology and Environment, China (2019HJ2096001006), the Second Tibetan Plateau Scientific Expedition and Research (STEP) program (2019QZKK0502), the Key Projects of the Joint Fund of the National Natural Science Foundation of China (U1802232), the Youth Innovation Promotion Association of Chinese Academy of Sciences (2019382), the Young Academic and Technical Leader Raising Foundation of Yunnan Province (2019HB039).

\section{References}

Chen YS, Deng T, Zhou Z, Sun H (2018) Is the east Asian flora ancient or not? National Science Review 5(6): 920-932. https://doi.org/10.1093/nsr/nwx156

Deng J, Drew BT, Mavrodiev EV, Gitzendanner MA, Soltis PS, Soltis ED (2015) Phylogeny, divergence times, and historical biogeography of the angiosperm family Saxifragaceae. Molecular Phylogenetics and Evolution 83: 86-98. https://doi.org/10.1016/j. ympev.2014.11.011

Haworth AH (1803) Miscellanea naturalia: Sive dissertationes variæ ad historiam naturalem spectantes. Typis J. Taylor, Londini, 155 pp.

Magota K, Sakaguchi S, Lee JS, Yamamoto M, Takahashi D, Nagano AJ, Setoguchi H (2021) Phylogeographic analysis of Saxifraga fortunei complex (Saxifragaceae) reveals multiple origins of morphological and ecological variations in the Japanese Archipelago. Molecular Phylogenetics and Evolution 163: e107230. https://doi.org/10.1016/j.ympev.2021.107230

Pan JT, Gu CZ, Huang SM, Wei ZF, Jin SY, Lu LD, Akiyama S, Alexander C, Bartholomew B, Cullen J, Gornall RJ, Hultgård U-M, Ohba H, Soltis DE (2001) Saxifragaceae. In: Wu ZY, 
Raven PH, Hong DY (Eds) Flora of China, vol. 8. Science Press, Beijing and Missouri Botanical Garden Press, St. Louis, 269-452. http://foc.eflora.cn/content.aspx?TaxonId=10800 Prieto JAF, Arjona JM, Sanna M, Pérez R, Cires E (2013) Phylogeny and systematics of Micranthes (Saxifragaceae): An appraisal in European territories. Journal of Plant Research 126(5): 605-611. https://doi.org/10.1007/s10265-013-0566-2

Soltis DE, Kuzoff RK, Conti E, Gornall R, Ferguson K (1996) matK and rbcL gene sequence data indicate that Saxifraga (Saxifragaceae) is polyphyletic. American Journal of Botany 83(3): 371-382. https://doi.org/10.1002/j.1537-2197.1996.tb12717.x

Soltis DE, Kuzoff RK, Mort ME, Zanis M, Fishbein M, Hufford L, Koontz J, Arroyo MK (2001) Elucidating deep-level phylogenetic relationships in Saxifragaceae using sequences for six chloroplastic and nuclear DNA regions. Annals of the Missouri Botanical Garden 88(4): 669-693. https://doi.org/10.2307/3298639

Sun H, Zhang JW, Deng T, Boufford DE (2017) Origins and evolution of plant diversity in the Hengduan Mountains, China. Plant Diversity 39(4): 161-166. https://doi.org/10.1016/j. pld.2017.09.004

Tkach N, Röser M, Hoffmann MH (2015a) Molecular phylogenetics, character evolution and systematics of the genus Micranthes (Saxifragaceae). Botanical Journal of the Linnean Society 178(1): 47-66. https://doi.org/10.1111/boj.12272

Tkach N, Röser M, Miehe G, Muellner-Riehl AN, Ebersbach J, Favre A, Hoffmann MH (2015b) Molecular phylogenetics, morphology and a revised classification of the complex genus Saxifraga (Saxifragaceae). Taxon 64(6): 1159-1187. https://doi.org/10.12705/646.4

Wang GF, Ye YS, Xing FW (2008) Saxifraga daqiaoensis (Saxifragaceae), a new species from Guangdong, China. Annales Botanici Fennici 45(3): 237-239. https://doi. org/10.5735/085.045.0313

Zhang JJ, Zhao WY, Meng KK, Liao WB, Wang L, Chen SF (2019a) Saxifraga shennongii, a new species of Saxifragaceae from Hunan Province, China. Phytotaxa 418(1): 079-088. https://doi.org/10.11646/phytotaxa.418.1.4

Zhang MH, Zhang XS, Nie ZL, Zhang DG, Meng Y (2017) Saxifraga kegangii (Saxifragaceae), a new species from Hunan Province of central China. Phytotaxa 309(2): 159-165. https:// doi.org/10.11646/phytotaxa.309.2.7

Zhang MH, Wang CY, Zhang C, Zhang DG, Li KG, Nie ZL, Meng Y (2019b) Phylogenetic relationships and biogeographic history of the unique Saxifraga sect. Irregulares (Saxifragaceae) from eastern Asia. Journal of Systematics and Evolution 58(6): 958971. https://doi.org/10.1111/jse.12547

Zhao WY, Meng KK, Fan Q, Jin JH, Liao WB (2019) Saxifraga damingshanensis (S. sect. Irregulares, Saxifragaceae), a new species from Guangxi, China. PhytoKeys 133: 95-103. https://doi.org/10.3897/phytokeys.133.36704

Zhang XJ, Liu ZC, Meng KK, Ding QL, Wang L, Liao WB (2018) Saxifraga luoxiaoensis (Saxifragaceae), a new species from Hunnan and Jaingxi, China. Phytotaxa 350(3): 291-296. https://doi.org/10.11646/phytotaxa.350.3.8

Zhang ZX, Chen SL, Gornall RJ (2015) Morphology and anatomy of the exine in Saxifraga (Saxifragaceae). Phytotaxa 212(2): 105-132. https://doi.org/10.11646/phytotaxa.212.2.1 